\title{
Analysis of Apple Fruit Value Chain in Southern Ethiopia; the Case of Chencha District
}

\section{Tamirat, Girma; Muluken, Philipos}

Agricultural Economics Research Process, Wondo Genet Agricultural Research Center, P.O. Box 198, Shashemene, Ethiopia.

Article No.: 100218043

Type: Research

DOI:10.15580/GJPBCS.2018.3.100218043

Submitted: 02/10/2018

Accepted: $29 / 10 / 2018$

Published: 03/12/2018

${ }^{*}$ Corresponding Author

Tamirat Girma

E-mail: tamirat.girma@ yahoo.com Phone: +2510912781053

Keywords: apple fruit, highland fruit, marketing margin, marketing constraints.
Ethiopia imported 1,328 tons of apple fruit valued 1,776,000 US dollar in 2016 and the import grows by $27 \%$ yearly. The study assessed the performance of apple fruit value chain produced in Chencha district and identified constraints along the chain. Multi stage sampling technique was employed to select 226 apple fruit producers from the district. Snowball sampling method was employed to collect primary data from the chain actors. A total of 4 collectors, 5 cooperatives, 2 assemblers, 2 wholesalers and 15 retailers were interviewed to pinpoint the performance of the chain. Descriptive statistics was used to analyze the data and supplemented by qualitative data obtained from the key informants and focus group discussion. Accordingly, highest marketing cost per kuintal of apple fruit was incurred by cooperatives (468.35 birr). About $97 \%, 71 \%$ and $54 \%$ of marketing cost of cooperatives, small collectors and district assemblers accounted to market searching cost respectively. Producers were more profitable and obtained the highest producers gross marketing margin when they sold apple through cooperatives. Poor agronomic management, lack of inputs, lack of organic certification, lack of proper harvesting and post-harvest handling, theft and rodent were major production constraints identified. Whereas unripe fruit trade, illegal trade, seasonality of supply and poor market coordination were major marketing constraints in the chain. Wholesale traders play a key role through balancing and controlling the supply and demand of the fruit. Therefore, it is necessary to create highland fruit marketing union to alleviate demonstrated marketing constraints. The government should work to alleviate the production constraints so that producers can be benefited from apple fruit production. 


\section{INTRODUCTION}

Apple (Malusdomestica) accounts for $50 \%$ of the world's deciduous fruit tree production. The leading apple growing country is China, producing about $41 \%$ of the world's apple; followed by United States, India, and Turkey. In Africa, the leading producer is South Africa, followed by Egypt and Kenya (USDA, 2013).

The introduction of apple tree to the tropical country Ethiopia is traced back to 1950s. British protestant missionaries have first introduced apple seedlings to plant in their home compound in Chencha town southwest of Ethiopia. However, the apple cultivation has been confined in and around Chencha district until recently (Girmay et al. 2014). The apple fruit production in Chencha district was about 15 tons per year in 2008 (SNV, 2008 cited in Girmay et al. 2014). However, in 2016 Chencha district apple production reached 144 tons (Chencha district Agriculture office). There is no clear information on the current country level production of apple fruit in Ethiopia.

According to Helgi library (2017), average apple per capita consumption in Ethiopia is estimated at 0.028 $\mathrm{kg}$ per a year, which is less than neighbouring countries like Djibouti (0.545), Kenya (0.212), Sudan (0.128), and Uganda (0.066). Based on per capita consumption, yearly apple demand of Ethiopia reaches about 2,856 tons. This indicated that about $46.4 \%$ of domestic demand of apple has been met from import.

Total import of tropical fruits (fresh apple, pear, and quinces) for the country was 808,990 and 1,342 tons in 2014, 2015 and 2016 G.C. respectively. Majority of this import $(97 \%, 98 \%$, and $99 \%$ respectively) was fresh apple fruit. Therefore, Ethiopia is net importer of apple fruit. It imported about 1,328 tons of apple valued $1,776,000$ US dollar only in 2016 G.C from different countries (ITC, 2017). Figure 1 indicates that the quantity and value of apple imported from abroad demonstrated an increasing trend. On average, the country's apple import increased by $27 \%$ annually. France has the lion share by supplying 520 (39.2\%) tones of apple for Ethiopia. South Africa (23.7\%) and USA $(12.8 \%)$ has the second and the third place. These three countries (France, South Africa and USA) together accounted $75.7 \%$ of the supply whereas Belgium, Italy, Chile, Turkey, Greece, Netherlands, Germany and Saud Arabia together have accounted the remaining part (ITC, 2017).

On the other side, domestic apple was receiving relatively lower price compared to the imported ones. For instance, retail price of domestic apple was 25 to 40 birr per kilogram; whereas it is 120 birr per kilogram for the imported one in Hawassa and Shashemene towns in 2017.

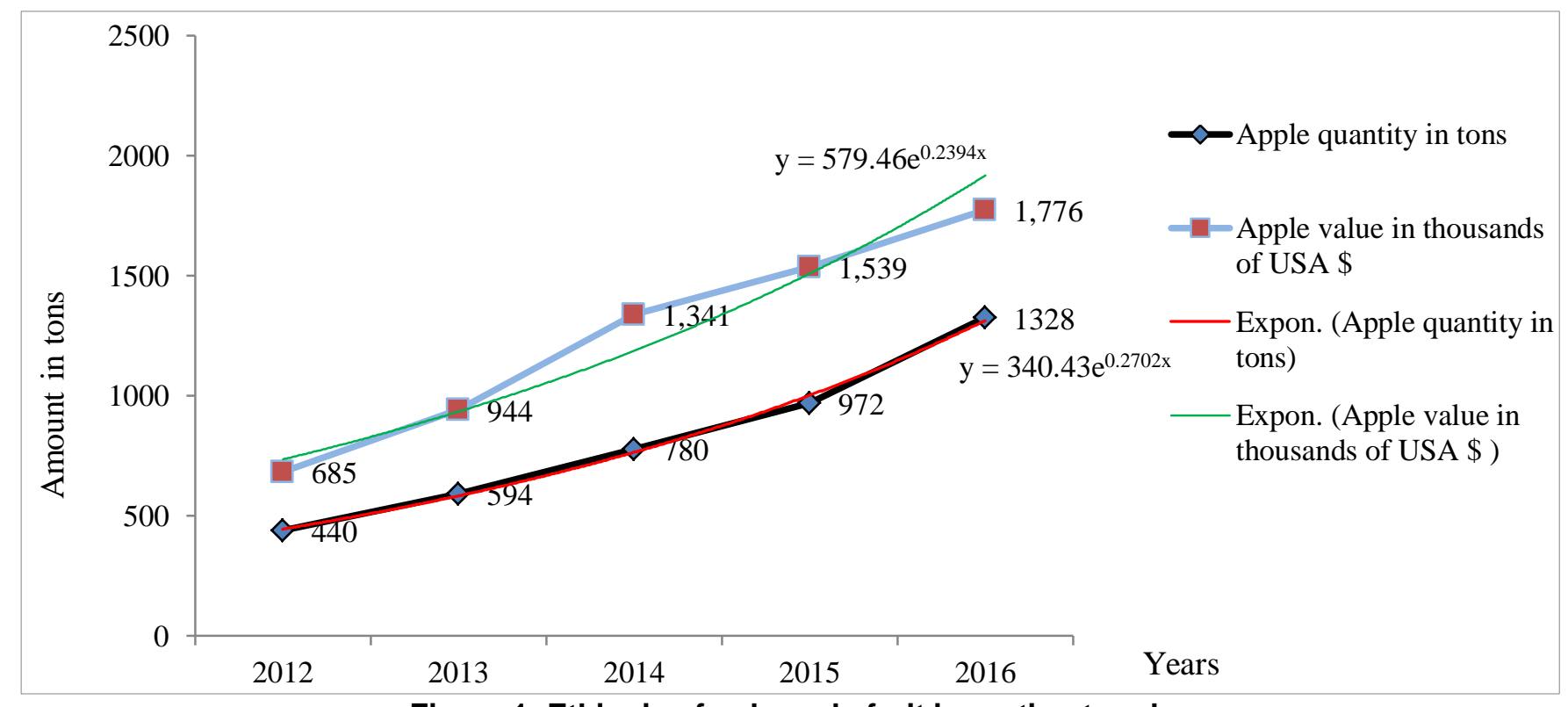

Figure 1: Ethiopian fresh apple fruit importing trends

Source: computed from ITC (2017)

\section{Objectives of the Study}

The general objective of this study was to assess the performance of apple fruit value chain in Chencha district of southern Ethiopia. The study specifically aimed to:
- identify the chain actors, their functions and relationships,

- identify production and marketing constraints along the value chain. 


\section{METHODOLOGY OF THE STUDY}

\section{Description of the Study Area}

Chencha is a district in the Southwest highlands of Ethiopia at an altitude ranging between 1600-3200 meters above the sea level. The agro-ecology of the district is suitable for tropical fruit production $(82 \%$ highland) and the mean annual rainfall ranges from $750 \mathrm{~mm}-1000 \mathrm{~mm}$. The major means of livelihood is subsistence rain-fed agriculture followed by traditional weaving. The soil types of the district are generally clay loam, red clay, verity soil and sandy with low productivity due to traditional and fragmented farming, low contents of organic matter and nitrogen (Girmay et. al.2014).

\section{Data Type, Source, and Method of Collection}

The analysis relied on primary data obtained from typical agents of the value chain combined with secondary data sources such as; official statistical data and previous studies on apple. Multi stage sampling technique was employed to select sample fruit producers. In the first stage, major fruit producer kebeles were selected purposively with the help of woreda experts. In the second stage, three producer kebeles were selected randomly from major fruit producer kebeles. Then fruit producer households were identified purposively. Finally, the primary data was collected from 226 randomly selected fruit producers in Doko Losha, Doko Kale and Doko Shaye kebeles through structured questionnaire. Snowball sampling method was employed to collect primary data from the other chain actors. An attempt was made to select representative sample whenever possible using simple random sampling by incorporating licensed and un-licensed traders, and to include respondents from each of the value chain stage. A total of 4 collectors, 5 cooperatives, 2 assemblers, 2 wholesalers and 15 retailers were interviewed to pinpoint the performance and the nature of the chain.

\section{Method of Data Analysis}

The data obtained from household survey through structured questionnaire were analyzed using SPSS version 20 and Microsoft offices excel 2007. Descriptive statistics such as percentage, frequency, mean, maximum, minimum and standard deviation were used to analyze the data.

\section{Analysis of the Value Chain and Marketing Margins}

Value chain is the full range of activities which are required to bring a product or service from conception through the different phases of production, delivery to final consumers, and final disposal after use. It is the sequence of activities required to make a product or provide a service (Kaplinsky and Morris, 2001). Value chain mapping is key tool in value chain analysis. A value chain map illustrates the way the product flows from producers to consumers and shows the type of actors involved. The study therefore employed mapping to describe and examine apple fruit value chain.

Estimates of the marketing margins are the best tools to analyze performance of market. Marketing margin was calculated by taking the difference between producers and consumer prices. The producers' share is the commonly employed ratio calculated mathematically as the ratio of producers' price to consumers' price.

$$
\mathrm{PS}=\frac{\mathrm{Pp}}{\mathrm{Cp}}=1-\frac{\mathrm{MM}}{\mathrm{Cp}}
$$

Where: $\mathrm{PS}=$ Producer's share, $\mathrm{Pp}=$ Producer's price, $\mathrm{Cp}=$ Consumer price and $\mathrm{MM}=$ marketing margin

Total marketing margin was calculated using the following formula. Computing the Total Gross Marketing Margin (TGMM) is related to the final price paid by the end buyer and is expressed as a percentage (Mendoza, 1995).

$$
\text { TGMM }=\frac{\text { Consumer Price-Producer Price }}{\text { Consumer Price }} \times 100
$$

Where, TGMM=Total gross marketing margin.

Net Marketing Margin (NMM) is the percentage over the final price earned by the intermediary as his net income; once his marketing costs are deducted.

$N M M=\frac{\text { Gross marketing margin }- \text { Marketing costs }}{\text { Consumer Price }} \times 100$

To find the benefit share of each actor the same concept was applied with some adjustments.

In analyzing margins, first the Gross Marketing Margin (GMM) was calculated. Gross Market margin will be computed as:

$$
G M M=\frac{\text { Consumer price-Marketing margin }}{\text { Consumer price }} \times 100
$$

Where, GMM = Gross market margin.

\section{RESULTS AND DISCUSSION}

\section{Demographic Characteristics of Households}

Table 1 portrayed that, from the 226 sample households, $32(14 \%)$ of them were female headed households. Average age of the respondents was 45 years, and it varied between 20 and 85 years. Therefore, the average age of the sample households lied in active working age. Most of the sample households (85\%) were literate and had an average of 6 years of schooling. Both national and regional average household size in rural areas is 5 
persons (CSA \& World Bank, 2013). However, an average family size of the sample households was 7 persons, which was higher than national family size of rural households. Dependency ratio of the sample households was $0.9(90 \%)$ that was nearly national and regional ratios (1.02 and 1.09 respectively) (CSA \& World 2013).

Table: 1 Demographic characteristic of sample households

\begin{tabular}{|c|c|c|c|c|c|}
\hline Variables & Observation(n) & Mean & Std.Dev. & Min. & Max. \\
\hline Age (years) & 226 & 45 & 13.31 & 20 & 85 \\
\hline Years spent in school & 226 & 6 & 4.23 & 0 & 16 \\
\hline Family size & 226 & 7 & 2.47 & 2 & 15 \\
\hline Dependency ratio & 225 & 0.9 & 0.77 & 0 & 4.5 \\
\hline & & \multicolumn{2}{|c|}{ Number } & \multicolumn{2}{|c|}{ Percent } \\
\hline \multirow[t]{2}{*}{ Sex } & Male & \multicolumn{2}{|c|}{194} & \multicolumn{2}{|c|}{86} \\
\hline & Female & \multicolumn{2}{|c|}{32} & \multicolumn{2}{|c|}{14} \\
\hline \multirow[t]{2}{*}{ Literacy } & Illiterate $(<0$ grade) & \multicolumn{2}{|c|}{33} & \multicolumn{2}{|c|}{14.6} \\
\hline & Literate ( $>0$ grade) & \multicolumn{2}{|c|}{193} & \multicolumn{2}{|c|}{85.4} \\
\hline
\end{tabular}

Source: Survey data (2016)

\section{Resource Ownership}

Land is primary requirement for agricultural production. The survey result revealed that the mean land holding of the households was 1.06 hectare and ranged 0.07 to 4.5 hectares. The average was below the national average 1.8 hectare (CSA \& World Bank, 2013) indicating land shortage was one of the constraints in crop production in the study area. On average households, allocate 0.23
(22\% of total land) hectare for tropical fruits. Availability of livestock indirectly determines availability of compost/manure applied on the fruit. The average livestock owned by the sample respondents were 2.74 TLU. Average beehive holding was below 1 per household, indicating unexploited opportunity as the study area has ample agro-forestry and agro-ecological favorability.

Table: 2 Resource ownership of sample households

\begin{tabular}{l|c|c|c|c|c|}
\hline Variables & Observation(n) & Mean & Std.Dev. & Min. & Max. \\
\hline Land owned (ha) & 226 & 1.06 & 0.65 & 0.07 & 4.5 \\
\begin{tabular}{|l|c|c|c|c|c|}
\hline $\begin{array}{l}\text { Land under fruit } \\
\text { production (ha) }\end{array}$ & 212 & 0.23 & 0.17 & 0.004 & 0.8 \\
\hline Livestock (TLU) & 226 & 0.5 & 2.74 & 0 & 11.54 \\
\hline Beehives (number) & 226 & 1.71 & 0 \\
\hline
\end{tabular}
\end{tabular}

Source: Survey data (2016)

\section{Highland Fruit Production in Chencha}

Highland fruit production is one of income generating activities since its introduction in 1950's, at Chencha area (Seifuet al. 2014). In Chencha, highland fruits mostly inter-cropped with beans, potatoes, barley and spices. According to the district agricultural office report, area coverage of fruit plantation was 1182 ha in 2016.
Apple, pear and plum are major highland fruit crops produced in the area. The survey shows that the average fruit production per tree during the survey year was 20,14, and 35 Kilograms for apple, pear, and plum respectively (Table 3 ). The productivity of apple found far below the historic tree in Tololla" village in Chencha, which gives $200 \mathrm{Kg}$ (Girmay et al. 2014).

Table: 3 Highland fruits productivity per tree

\begin{tabular}{|l|c|c|c|c|}
\hline Variable & Mean (kg) & Std. Dev. & Min. & Max. \\
\hline Apple & 20 & 14.74 & 4 & 125 \\
\hline Pear & 14 & 10.20 & 2 & 90 \\
\hline Plum & 35 & 42.36 & 8 & 300 \\
\hline
\end{tabular}

Source: Survey data (2016) 


\section{Value Chain of Apple Fruit Produced in Chencha District}

It was estimated that 144 tons of apple fruit was produced and marketed in Chencha districts in 2016. Five main alternative marketing channels were identified in apple fruit marketing. The major marketing channels were represented in Figure 3. The main outlets that fruit reached the market was through urban assemblers, cooperatives and collectors, with an estimated percentage share of $41 \%, 31 \%$ and $28 \%$, respectively (Figure 2). The highest volume of apple fruit was marketed through channel II (48.41 tons) followed by channel I (44.64 tons) and channel IV (29.84 tons).

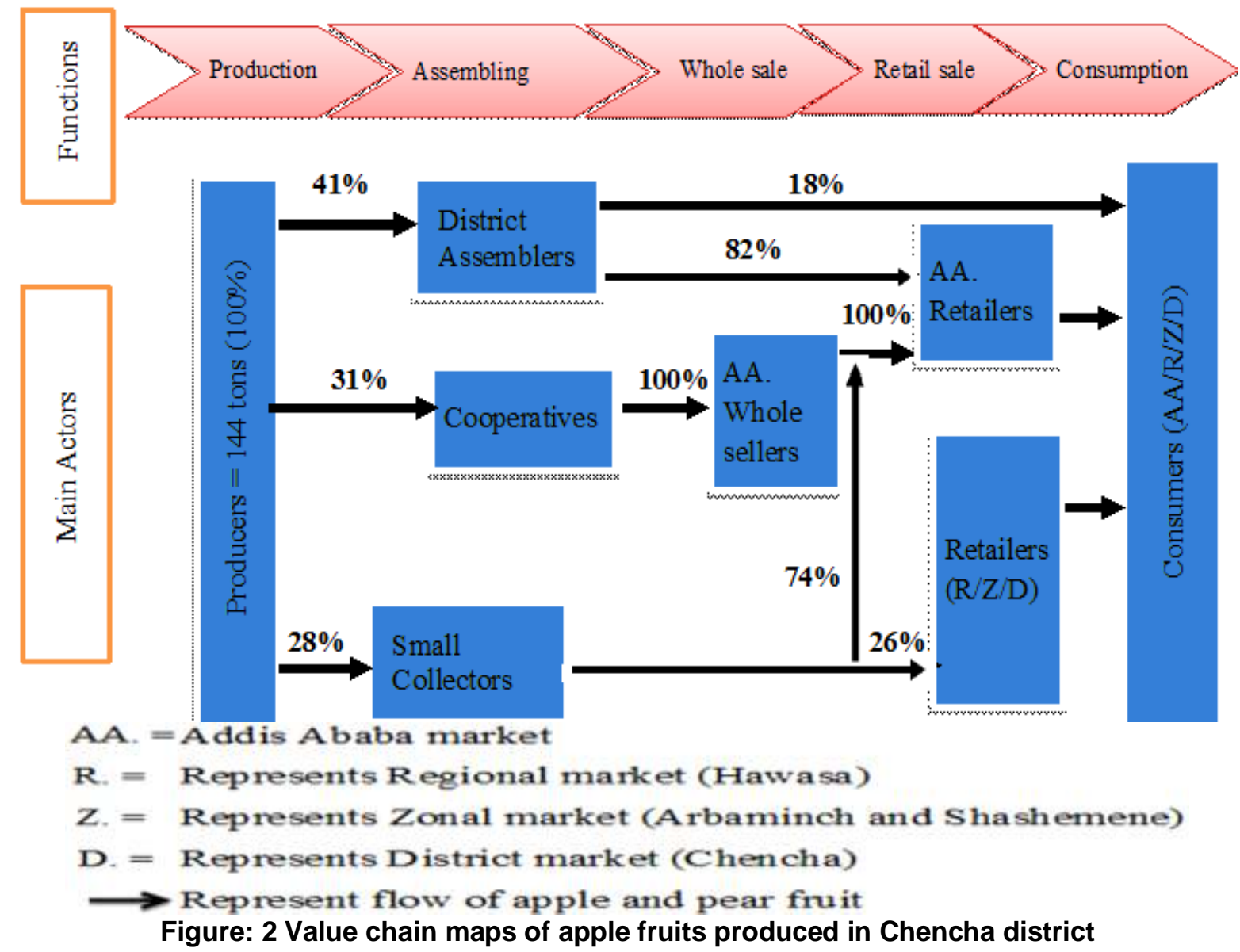

Source: own sketch from survey result, 2016

I. Producers $\longrightarrow$ Coopratives $\longrightarrow$ A.A.wholesaler $\longrightarrow$ AA.Retailers $\longrightarrow$ Consumers $=44.64$ tons
II. Producers $\longrightarrow$ District Assemblers $\longrightarrow$ AA.Retailers $\longrightarrow$ Consumers $=48.41$ tons
III. Producers $\longrightarrow$ District Assemblers $\longrightarrow$ Consumers $=10.63$ tons
IV.Producers $\longrightarrow$ Small Collectors $\longrightarrow$ AA. Retailers $\longrightarrow$ Consumers $=29.84$ tons
V.Producers $\longrightarrow$ Small Collectors $\longrightarrow$ R/Z/D Retailers $\rightarrow$ Consumers $=10.48$ tons

Figure: 3 Major market channels of Chencha district apple fruits

Source: own sketch from survey result, 2016 


\section{Marketing Cost of Apple Fruit Traders}

Table 4 summarizes marketing costs of each actors participating in the value chain. Highest marketing cost per kuintal of apple was incurred by cooperatives (468.35 birr) and about $97 \%, 71 \%$ and $54 \%$ of marketing cost of cooperatives, small collectors and district assemblers accounted to market searching cost respectively. Cost of transportation had the largest share (59\%) for Addis Ababa wholesalers. This was due to Addis Ababa wholesalers were responsible to cover cost of transportation until the fruit reaches their shop at Addis Ababa.

Table 4: Marketing cost of apple fruit traders (birr/kuintal)

\begin{tabular}{|c|c|c|c|c|c|c|c|}
\hline Items & Producers & Cooperatives & $\begin{array}{l}\text { District } \\
\text { Assemblers }\end{array}$ & $\begin{array}{l}\text { AA. } \\
\text { Wholesalers }\end{array}$ & $\begin{array}{l}\text { AA. } \\
\text { Retailers }\end{array}$ & $\begin{array}{l}\text { R/Z/D } \\
\text { Retailers }\end{array}$ & $\begin{array}{l}\text { Small } \\
\text { Collectors }\end{array}$ \\
\hline Cleaning cost & & $5(1)$ & $25(6)$ & $10(6)$ & & & \\
\hline Market search cost & & $455(97)$ & $220(54)$ & & & & $100(71)$ \\
\hline $\begin{array}{l}\text { Loading and } \\
\text { unloading cost }\end{array}$ & & & $10(2)$ & $10(6)$ & & & $10(7)$ \\
\hline Transport cost & $15(100)$ & & $100(25)$ & 100(59) & & & $20(14)$ \\
\hline \multicolumn{8}{|l|}{ Storage cost } \\
\hline $\begin{array}{l}\text { Labor cost for } \\
\text { packaging }\end{array}$ & & & & & $10(29)$ & $10(29)$ & \\
\hline $\begin{array}{l}\text { Packaging Material } \\
\text { cost }\end{array}$ & & & $42(10)$ & $42(25)$ & $25(71)$ & $25(71)$ & $10(7)$ \\
\hline Tax & & $8.35(2)$ & $8.35(2)$ & $8.35(5)$ & & & \\
\hline $\begin{array}{l}\text { Total marketing } \\
\text { costs }\end{array}$ & 15 & 468.35 & 405.35 & 170.35 & 35 & 35 & 140 \\
\hline
\end{tabular}

Values in bracket is percentage of the cost

Note: $A A=$ Addis Ababa market, $R / Z / D=$ Regional, Zonal, District level markets respectively

Source: Own survey result (2017)

\section{Distribution of Benefits among Apple Value Chain Actors}

The total gross marketing margin (TGMM) was highest in channel IV which was $60 \%$ of the consumers' price. Therefore, channel IV demonstrated less fair distribution of benefit. Producers obtained the highest gross marketing margin and net marketing margin when they sale apple through cooperatives (channel I). That is apple producers obtained $60 \%$ of consumer price as gross marketing margin (GMMp) and they obtained the lowest gross marketing margin when they sale through channel IV which accounted for $40 \%$ of consumers' price.

Producers obtained the highest profit (2743 birr/ku) and highest profit share (64\%) in channel I
(Table 5). Among different actors, collectors obtained highest profit in channel IV which accounted $49 \%$ of the total profit made along the channel which is double of producer's profit share in the channel.

Generally, district level assemblers and collectors relatively got high profit share compared to other actors in the value chain which was not reasonable to their contribution in the chain. Assemblers obtained about $34 \%$ and $42 \%$ of the profit made in channel II and III respectively from apple trade (Table 5). Collectors obtained about $49 \%$ and $31 \%$ of the profit made in channel IV and V respectively from apple trade. Benefit distribution among market actors found more likely fair in channel I compared to other marketing channels. 
Table: 5 Marketing margins in apple fruit value chain

\begin{tabular}{|c|c|c|c|c|c|c|}
\hline \multirow[t]{2}{*}{ Value chain Actors } & \multirow[t]{2}{*}{ Cost/profit items (birr/Ku) } & \multicolumn{5}{|c|}{ Marketing channels } \\
\hline & & $\mathrm{I}$ & II & III & IV & V \\
\hline \multirow[t]{7}{*}{ Producers } & Selling price & 3300 & 2000 & 3200 & 1000 & 1800 \\
\hline & Production cost & 542 & 542 & 542 & 542 & 542 \\
\hline & Marketing cost & 15 & 15 & 15 & 15 & 15 \\
\hline & Value added/profit & 2743 & 1443 & 2643 & 443 & 1243 \\
\hline & Share of profit (\%) & 64 & 45 & 58 & 25 & 45 \\
\hline & GMMp (\%) & 60 & 48 & 58 & 40 & 51 \\
\hline & NMMp (\%) & 50 & 41 & 48 & 18 & 44 \\
\hline \multirow[t]{7}{*}{ Collectors } & Purchasing price & & & & 1000 & 1800 \\
\hline & Selling price & & & & 2000 & 2800 \\
\hline & Marketing cost & & & & 140 & 140 \\
\hline & Value added & & & & 860 & 860 \\
\hline & Share of profit (\%) & & & & 49 & 31 \\
\hline & GMMcl (\%) & & & & 40 & 29 \\
\hline & NMMcl (\%) & & & & 34 & 25 \\
\hline \multirow[t]{7}{*}{ District level Assemblers } & Purchasing price & & 2000 & 3200 & & \\
\hline & Selling price & & 3500 & 5500 & & \\
\hline & Marketing cost & & 405 & 405 & & \\
\hline & Value added & & 1095 & 1895 & & \\
\hline & Share of profit (\%) & & 34 & 42 & & \\
\hline & GMMdass (\%) & & 36 & 42 & & \\
\hline & NMMdass (\%) & & 26 & 34 & & \\
\hline \multirow[t]{7}{*}{ Cooperatives } & Purchasing price & 3300 & & & & \\
\hline & Selling price & 3800 & & & & \\
\hline & Marketing cost & 468 & & & & \\
\hline & Value added & 32 & & & & \\
\hline & Share of profit (\%) & 1 & & & & \\
\hline & GMMco (\%) & 9 & & & & \\
\hline & NMMco (\%) & 1 & & & & \\
\hline \multirow[t]{7}{*}{ A.A. wholesalers } & Purchasing price & 3800 & & & & \\
\hline & Selling price & 5000 & & & & \\
\hline & Marketing cost & 170 & & & & \\
\hline & Value added & 1030 & & & & \\
\hline & Share of profit (\%) & 24 & & & & \\
\hline & GMMaw (\%) & 22 & & & & \\
\hline & NMMaw (\%) & 19 & & & & \\
\hline \multirow[t]{7}{*}{ A.A. retailers } & Purchasing price & 5000 & 3500 & & 2000 & \\
\hline & Selling price & 5500 & 4200 & & 2500 & \\
\hline & Marketing cost & 35 & 35 & & 35 & \\
\hline & Value added & 465 & 665 & & 465 & \\
\hline & Share of profit (\%) & 11 & 21 & & 26 & \\
\hline & GMMar (\%) & 9 & 17 & & 20 & \\
\hline & NMMar (\%) & 8 & 16 & & 19 & \\
\hline \multirow[t]{7}{*}{ R/Z/D. retailers } & Purchasing price & & & & & 2800 \\
\hline & Selling price & & & & & 3500 \\
\hline & Marketing cost & & & & & 35 \\
\hline & Value added & & & & & 665 \\
\hline & Share of profit (\%) & & & & & 24 \\
\hline & GMMrzdr (\%) & & & & & 20 \\
\hline & NMMrzdr (\%) & & & & & 19 \\
\hline \multicolumn{2}{|c|}{ TGMM (\%) } & 40 & 52 & 42 & 60 & 49 \\
\hline \multirow{2}{*}{\multicolumn{2}{|c|}{$\begin{array}{c}\text { NMM (\%) } \\
\text { Total profit made/ku }\end{array}$}} & 27 & 42 & 34 & 52 & 43 \\
\hline & & 4269 & 3203 & 4538 & 1768 & 2768 \\
\hline
\end{tabular}

Source: Own survey result (2017), Ku: kuintal (1Ku =100 Kg) 


\section{Value Chain Constraints}

\section{Production constraints}

Input supply: Chencha district is known for its source of highland fruit seedling nationally. Apple, pear and plum were the three-important highland fruit seedlings prepared in Chencha. Seedling trade was very important source of income in the district. However, now a day the demand for seedling reported sharply declining. Additionally, illegal seedling trade was eroding the trust on viability of the seedling because illegal traders did not worry for the quality of the seedling rather they only focus the quantity and the money that could be obtained from the sale. Illegal traders gather seedling from farmers without consideration of quality and sell it without agro-ecological requirement, which finally leads to dried or unrewarding trees.

Poor agronomic management: agronomic management determines the quality and production of fruits. For instance, Girmay et al. (2014) indicated pruning enhances apple fruit production and quality through increased efficiency of light utilization, ease of air circulation through the canopy and decrease incidence of fungal disease. Apple fruit production needs intensive horticultural and agronomic managements like timely thinning, pruning, training, watering and applying adequate amount of compost which was not done adequately in the district. In Chencha apple fruit production mostly relied on rainfall and not irrigated adequately. The problem manifested by decreased purity of the fruit (scared, spotted (tekateko) or cracked fruit) according to district experts.

Lack of production inputs: producers pointed out that inputs like scissor, saw, harvesting, and packing materials were crucial in fruit production but not available in the district. There was no supplier of these materials in the district. Key informant interview indicated that sometimes domestically produced pruning and thinning materials supplied by cooperatives. But domestically produced materials did not have the required quality, easily broken and did not properly work as producers blame. According to Chencha highland fruit cooperative, which has around 620-member producers, scissors and saws that were bought by World vision from Switzerland and distributed for producers were durable and demanded by the producers but not accessible.

Lack of organic certification: apple fruits produced in Chencha were free of any chemical contact and fully organic. Producers did not use chemical fertilizers, pesticides, and herbicides. They controlled pests and disease using bio-chemicals like garlic and arthimisia solution. However, producers were not certified for organic production, and did not benefit from organic product they supply. There was no organization that facilitates organic certification for the producers.
Theft and Rodent: theft was another challenge in the district as far as apple fruit production is concerned. Producers reported that their fruit was stolen from their orchard either in the night or during heavy rain. Additionally, rodent attack was a challenge faced by producers.

\section{Marketing constraints:}

Unripe apple fruit trade: producers could be benefited more from the production if they could supply ripe fruit to the market. However, some producers did not accept this because they prefer to sell all fruits (ripen and unripe) at a time for collectors in intention of getting money for their immediate expenses as fruit is main source of income from February to May in the area. Producers blame cooperatives and wholesalers for sorting their fruit for quality and rejecting unripe and lowquality fruits.

Illegal trade: There were no registered fruit collectors in the district. They bought fruits from producers at farm gate and the district market. They bought fruits by guessing the kilogram using plastic bag (pestal) and sometimes using spring balance. Farmers reported these buyers bought fruit without sorting for quality but payed lower price. According to key informants these buyers (collectors) cheated producers by using tied balance and enlarging the plastic bag (pestal) they used to guess the kilogram.

Seasonality of supply: apple fruit supply reported to fluctuate seasonally. The season of lowest fruit supply started from main rainy season June to mid-November when also prices were the highest. Fresh fruit supply started to rise in January and reached its peak in April and May. Generally, imported fruit tend to be more competitive than produced domestically, in terms of quality and sustainability of the supply.

Poor market coordination and information flow along the chain: Traders incur high market search cost because of poor communication and market coordination.

\section{CONCLUSIONS AND RECOMMENDATIONS}

Low quality apple fruit was found to be a critical problem that decreases the acceptance of the fruit. Therefore, there is a need of third party-controlled grading and quality standards which will help to reduce the quality risks linked to unripe fruit that undermined fruit price.

There was limited value adding activities that could improve the profit margin of value chain actors. Hence, introduction of packing house and cold storage in fruit production area having facilities like washing, 
waxing, grading, packing and pre-cooling is crucial. Processing options should be explored and introduced into the value chain to use opportunity that could be obtained from value addition.

As producers enjoyed higher profit margin from primary cooperatives, cooperatives should have to be supported to have warehouse centers at central market to maintain the supply and quality of the fruit. The management of the cooperatives needs to work to satisfy competition requirements such as seasonality and quality of the fruit. Extending the fruit supply period and managing oversupply during peak harvest time also helps to control price fluctuations.

Producers' preferred to sell both good quality and less quality fruits for low price rather than sorting the fruits for quality. This was due to absence of alternative market outlets for less quality fruits in the area. Therefore, exploring corresponding market outlets for low-quality fruits might raise the dreams of additional income from the fruit for Chencha community.

Even if Ethiopia had considerable demand for apple fruit, consumers preferred to consume the imported apple fruit, which was not organic than domestic apple fruit. Promotion of organic fruit should be increased to make the consumers aware and enhance the demand for domestic apple fruit.

Smallholder growers lacked modern business farming knowledge; they poorly managed their fruit farms and produced little amount of fruit per tree.
Therefore, government needs to focus on training and awareness creation in this regard.

\section{REFERENCES}

Central Statistical Agency (CSA) \& World Bank (2013). Ethiopia Rural Socioeconomic survey (ERSS).

Girmay G., Menza M., Mada M. and Abebe T. (2014). Empirical Study on Apple Production, Marketing and its Contribution to Household Income in Chencha District of Southern Ethiopia. Scholarly Journal of Agricultural Science Vol. 4(3), pp. 166-175

Helgilibrary:http://www.helgilibrary.com/indicators/appleconsumption-per-capita/ethiopia/ [accessed on August 29/2017]

Kaplinsky, R. and M. Morris, (2001). A handbook of value chain analysis. Working paper prepared for the IDRC, Institute for Development Studies, Brighton, UK

Mendoza, G. (1995). A premier on marketing channel and margins. Lyme Rimer Publishers Inc., USA.

Seifu F., Sabura S., Agena A., Guchie G., Fantahun W. and Belete Y. (2014). Survey on Apple Production and Variety Identification in Chencha District of Gamo Gofa Zone, Southern Ethiopia.

United States Department of Agriculture Foreign Agricultural Service (2013). Fresh deciduous fruit (apples, grapes and pears): World Markets and Trade. A study report by USDA, USA. 